\title{
Implementasi MPPT Panel Surya Berbasis Algoritma Perturbasi \& Observasi (PO) Menggunakan Arduino
}

\author{
Haris Masrefol ${ }^{1}$, dan Muldi Yuhendri ${ }^{2}$ \\ 1,2Jurusan Teknik Elektro Fakultas Teknik, Universitas Negeri Padang \\ Air Tawar, Padang - Sumatera Barat, Indonesia \\ harismasrefol@gmail.com ${ }^{1}$, muldiy@ft.unp.ac.id ${ }^{2}$
}

\begin{abstract}
Solar panels are a renewable energy power plant that uses sunlight as its main energy source. The power generated by solar panels are determined by the size of the solar panels, solar radiation and temperature. The power of the solar panels is also determined by the output voltage of the solar panels. To get the maximum output power at any time, it is necessary to adjust the output voltage of the solar panel. This study proposes controlling the maximum output power of solar panels, also known as maximum power point tracking (MPPT) by adjusting the output voltage of the solar panels using a buck converter. The buck converter output voltage regulation at the maximum power point of the solar panel is designed with the Perturbation and Observation (PO) algorithm which is implemented using an Arduino Mega 2560. This MPPT control system is applied to $4 \times 50$ Watt-Peak (WP) solar panels which are connected in parallel. The experimental results show that the proposed MPPT control system with the PO algorithm has worked well as expected. This can be seen from the output power generated by the solar panels already around the maximum power point at any change in solar radiation and temperature.
\end{abstract}

Keywords - Solar panel, MPPT, arduino, perturbation \& observation, buck converter

Abstrak - Panel surya adalah salah satu pembangkit listrik energi terbarukan yang menggunakan cahaya matahari sebagai sumber energi utamanya. Daya yang dihasilkan panel surya ditentukan oleh ukuran panel surya, radiasi cahaya matahari dan temperatur. Daya panel surya juga ditentukan oleh tegangan keluaran panel surya. Untuk mendapatkan daya output maksimum setiap saat, perlu dilakukan pengaturan tegangan keluaran panel surya. Penelitian ini mengusulkan pengendalian daya output maksimum panel surya yang disebut juga dengan maximum power point tracking (MPPT) dengan cara mengatur tegangan keluaran panel surya menggunakan konverter buck. Pengaturan tegangan keluaran konverter buck pada titik daya maksimum panel surya dirancang dengan algoritma Perturbasi dan observasi (P0) yang diimplementasikan menggunakan arduino Mega 2560. Sistem kendali MPPT ini diterapkan pada panel surya $4 \times 50$ WattPeak (WP)yang dikoneksikan secara parallel. Hasil pengujian menunjukan bahwa sistem kendali MPPT yang diusulkan dengan algoritma PO telah bekerja dengan baik sesuai dengan yang diharapkan. Hal ini dapat dilihat dari daya output yang dihasilkan panel surya sudah berada di sekitar titik daya maksimum pada setiap perubahan radiasi cahaya matahari dan temperatur.

Kata kunci- Panel surya, MPPT, arduino, perturbasi \& observasi, konverter buck

\section{Pendahuluan}

Pembangkit listrik tenaga surya adalah salah satu jenis pembangkit listrik dari sumber energi baru dan terbarukan yang mulai banyak dikembangkan di Indonesia. Pembangkit listrik tenaga surya ini bekerja dengan cara memanfaatkan energi cahaya matahari untuk dikonversikan menjadi energi listrik menggunakan solar cell. Daya yang dihasilkan solar cell ini ditentukan oleh jumlah cell yang digunakan, radiasi cahaya matahari dan temperatur pada solar cell. Daya yang lebih besar dapat diperoleh dengan memperbanyak solar cell yang disusun sedemikian rupa dalam bentuk panel, yang disebut juga dengan panel surya [1]-[2].

Selain radiasi cahaya matahari dan temperatur, daya output panel surya ini juga dipengaruhi oleh tegangan keluaran panel surya. Dengan mengatur tegangan keluaran panel surya kita dapat mengoperasikan panel surya pada titik daya maksimum. Konsep ini disebut juga dengan Maximum Power Point Tracking (MPPT) pada panel surya [3]. Pengaturan tegangan keluaran pada titik daya maksimum panel surya umumnya dilakukan menggunakan konverter dc-dc, seperti konverter buck, boost, buck boost, sepic dan sebagainya [4]-[5]. Sistem MPPT yang diusulkan dalam penelitian ini dirancang dengan menggunakan konverter buck. Konverter ini dipilih karena tegangan keluaran yang yang diharapkan lebih rendah dari tegangan keluaran panel surya. Hal ini sesuai dengan karakteristik konverter buck yang memiliki tegangan keluaran lebih kecil dari tegangan masukan [6].

Pengaturan tegangan keluaran pada titik daya maksimum panel surya dapat dilakukan dengan mengatur duty cycle switch konverter buck. Duty cycle yang tepat 
untuk tegangan pada titik daya maksimum perlu dicari agar panel tetap menghasilkan daya maksimum pada setiap variasi radiasi matahari dan temperatur. Pencarian duty cycle switch konverter untuk MPPT panel surya ini biasanya menggunakan algoritma MPPT. Telah banyak algoritma MPPT yang dikembangkan untuk mencari nilai duty cycle konverter ini, seperti algoritma perturbasi dan observasi (PO) [7]-[9], algoritma peningkatan konduktansi [10]-[12] dan algoritma berbasis kecerdasan buatan [13][14]. Setiap algoritma memiliki kelebihan dan kekurangan. Penelitian ini mengusulkan algoritma PO untuk mengatur tegangan keluaran konverter buck pada sistem kendali MPPT panel surya. Algoritma ini dipilih karena sederhana dan mudah diimplementasikan [7]. Algoritma PO ini diimplementasikan untuk Arduino Mega 2560 yang diprogram dengan menggunakan Simulink matlab. Sistem kendali MPPT yang diusulkan akan diterapkan pada panel surya 50 WP yang dipasang secara parallel sebanyak empat buah.

\section{Metode}

Penelitian tentang sistem kendali MPPT berbasis algoritma PO ini dilakukan dalam bentuk eksperimen dengan tahapan mencakup perancangan, pembuatan alat dan pengujian. Alat sistem kendali MPPT yang dibuat mencakup empat buah panel surya $50 \mathrm{WP}$, konverter buck, sensor arus, sensor tegangan, rangkaian gate driver, catu daya, Arduino mega 2560 dan PC yang dilengkapi dengan software Matlab untuk pemograman Arduino. Gambar 1 menunjukan blok diagram sistem kendali MPPT berbasis algoritma PO yang diusulkan dalam penelitian ini.

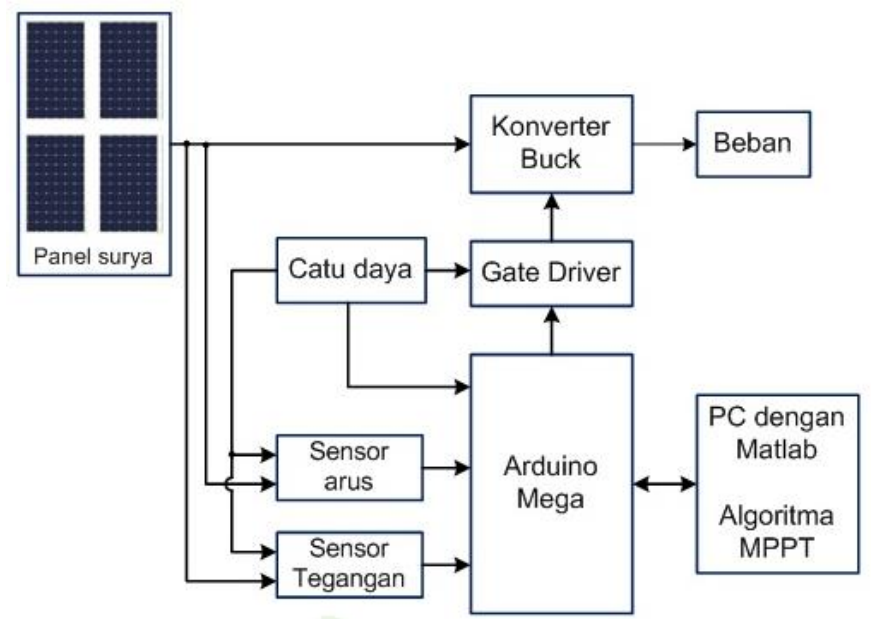

Gambar 1. Blok diagram penelitian

Gambar 1 menunjukan bahwa system kendali MPPT berbasis algoritma PO dirancang dengan menggunakan Arduino mega yang diprogram dengan Simulink Matlab. Prinsip kerja dari alat ini adalah sensor arus dan sensor tegangan akan mendeteksi tegangan dan arus panel surya yang menjadi input bagi Arduino untuk mengeksekusi system kendali MPPT berbasis algoritma PO yang dibuat dalam Simulink Matlab. Algoritma PO akan mencari duty cycle switch knverter buck berdasarkan perubahan daya dan tegangan panel surya, dimana perubahan daya dan perubahan tegangan ini dapat dihitung dari nilai arus dan tegangan yang diperoleh dari sensor arus dan sensor tegangan. Duty cycle yang diperoleh dari algoritma PO ini menghasilkan pulsa PWM yang akan memodulasi switch konverter buck melalui gate driver, sehingga konverter buck akan mengendalikan tegangan keluaran panel surya pada nilai tegangan untuk titik daya maksimum. Hal ini membuat panel surya akan beroperasi pada titik daya maksimum.

\section{Algortima Pertubasi dan Observasi (P0)}

Sistem kendali MPPT pada panel surya berfungsi untuk mengendalikan daya keluaran panel surya agar maksimum pada setiap saat. Pengendalian daya pada titik maksimum dilakukan dengan mengatur tegangan keluaran panel surya menggunakan converter daya. Konverter daya yang digunakan dalam penelitian ini adalah konverter buck. Konverter ini dipilih dengan tujuan agar tegangan keluaran converter lebih rendah dari tegangan panel surya. Hal ini bisa diterapkan dengan menggunakan converter buck, karena karakteristiknya yang memiliki tegangan keluaran lebih rendah dari tegangan masukan [15]. Pengaturan tegangan keluaran konverter pada titik daya maksimum ini dilakukan dengan mengatur duty cycle switch konverter. Pada system kendali MPPT panel surya, nilai duty cycle untuk tegangan keluaran pada titik daya maksimum dicari dengan menggunakan algoritma MPPT. Penelitian ini mengusulkan algoritma PO untuk mencari nilai duty cycle tersebut.

Algoritma PO Berfungsi untuk mencari nilai duty cycle switch konverter berdasarkan perubahan daya dan tegangan panel surya. Gambar 2 menunjukan prinsip kerja algoritma PO dalam mencari nilai duty cycle berdasarkan perubahan daya dan tegangan panel surya.

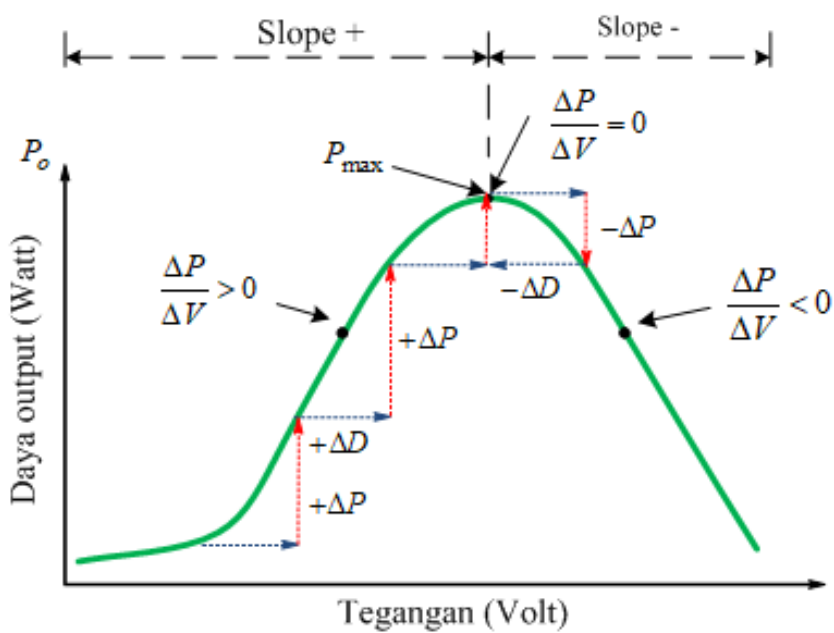




\section{Gambar 2. Prinsip Kerja Algoritma PO}

Gambar 2 menunjukan bahwa titik daya maksimum terjadi saat perubahan daya per perubahan tegangan sama dengan nol. Ketika nilai perubahan daya per perubahan tegangan besar dari nol, maka nilai duty cycle akan ditambah. sebaliknya, ketika nilai perubahan daya per perubahan tegangan kecil dari nol, maka nilai duty cycle akan dikurangi. Berdasarkan prinsip kerja algoritma PO pada Gambar 2, maka nilai duty cycle sebagai keluaran algoritma PO dapat dipresentasikan dalam Persamaan berikut :

(1)

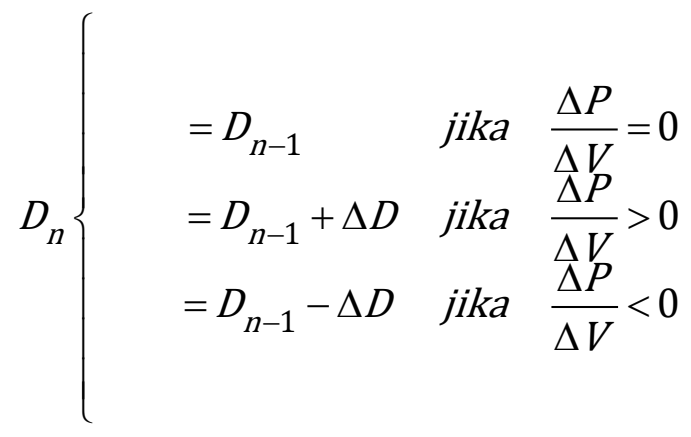

Dengan

$$
\begin{aligned}
& P=I \times V \\
& \Delta P=P_{n}-P_{n-1} \\
& \Delta V=V_{n}-V_{n-1}
\end{aligned}
$$

Keterangan:

$V=$ Tegangan (Volt)

$I \quad=$ Arus (Ampere)

$P=$ Daya $($ Watt $)$

Algoritma PO akan terus mencari nilai duty cycle berdasarkan evaluasi nilai perubahan tegangan dan daya panel surya. Dengan konsep ini, maka nilai duty cycle akan diupdate terus, sehingga panel surya akan tetap beroperasi pada titik daya maksimum setiap saat. Perubahan daya dan tegangan dapat dihitung berdasarkan nilai tegangan dan arus yang diperoleh dari sensor tegangan dan sensor arus yang diinputkan pada pin input analog Arduino. Sensor arus yang digunakan adalah sensor ACS712, sedangkan sensor tegangan diimplementasikan dengan rangkaian pembagi tegangan, seperti yang ditunjukan oleh Gambar 3.
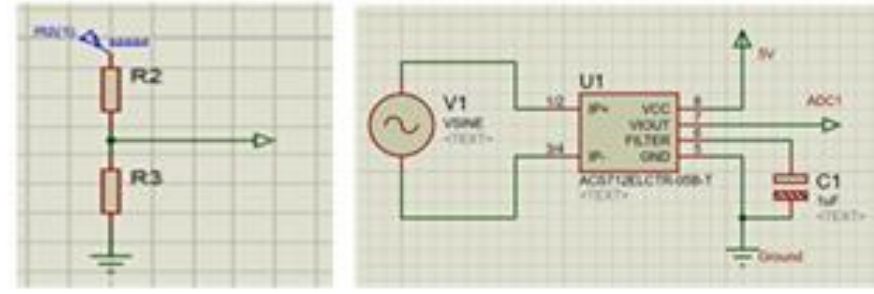

\section{Gambar 3. Pembagi tegangan dan sensor arus}

Nilai duty cycle sebagai keluaran algoritma PO akan dikonversikan menjadi pulsa PWM melalui pin PWM arduino. Pulsa PWM ini akan dinaikan nilai tegangannya melalui rangkaian gate driver agar bisa memodulasi gate switch konverter. Dalam penelitian ini, switch semikonduktor yang digunakan pada konverter buck adalah MOSFET IRF840, sedangkan gate driver menggunakan IR2184S. Gambar 4 menunjukan skema rangkaian gate driver MOSFET yang digunakan dalam penelitian ini.

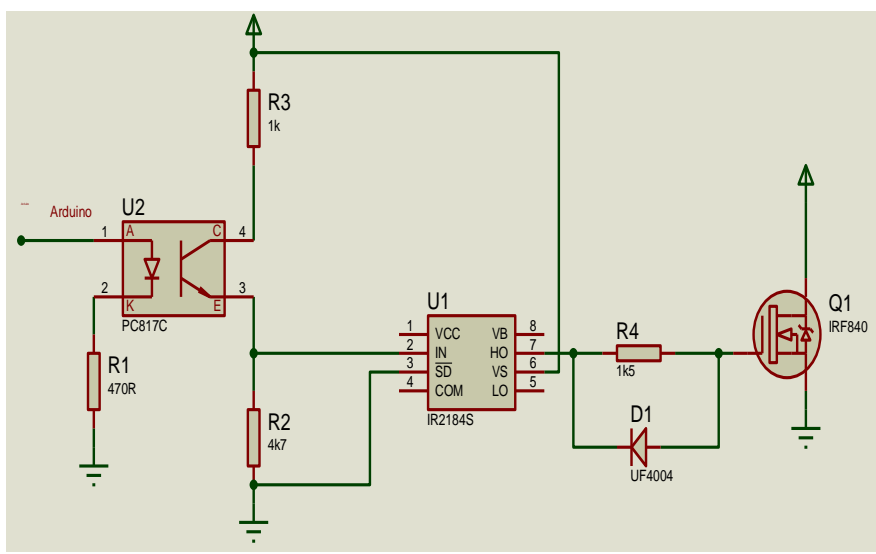

Gambar 4. Rangkaian Gate driver.

Algoritma MPPT dengan metode PO dibuat dengan menggunakan Simulink Matlab. Gambar 5 menunjukan algortima PO dalam Simulink Matlab.

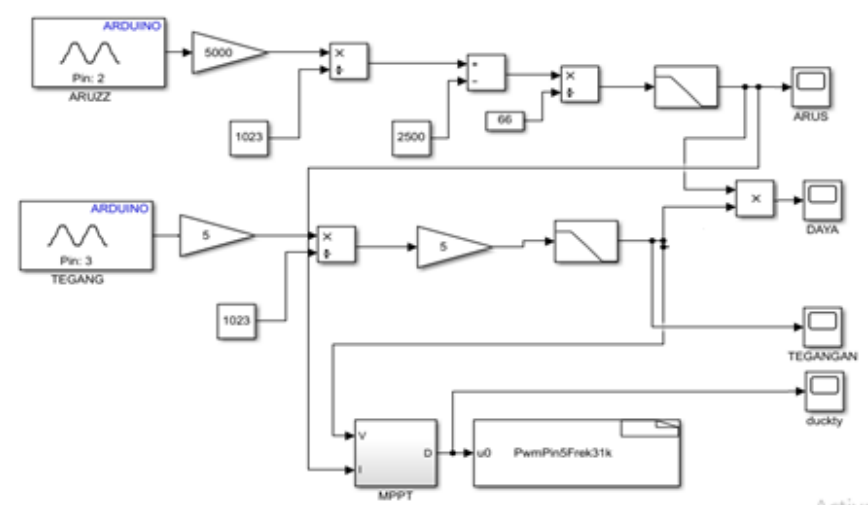

Gambar 5. Algoritma PO dalam Simulink Matlab 


\section{HASIL DAN PEMBAHASAN}

Setelah selesai membuat alat sistem kendali MPPT berbasis algoritma PO, selanjutnya dilakukan pengujian untuk melihat kinerja dari alat tersebut. Alat diuji pada panel surya $50 \mathrm{WP}$ yang dihubungkan secara parallel dengan beban resistor. Panel surya dipasang di atas atap dengan terminalnya di labor. Gambar 6 menunjukan panel surya yang yang terpasang di atas atap dan instalasi alat system kendali MPPT di dalam laboratorium.
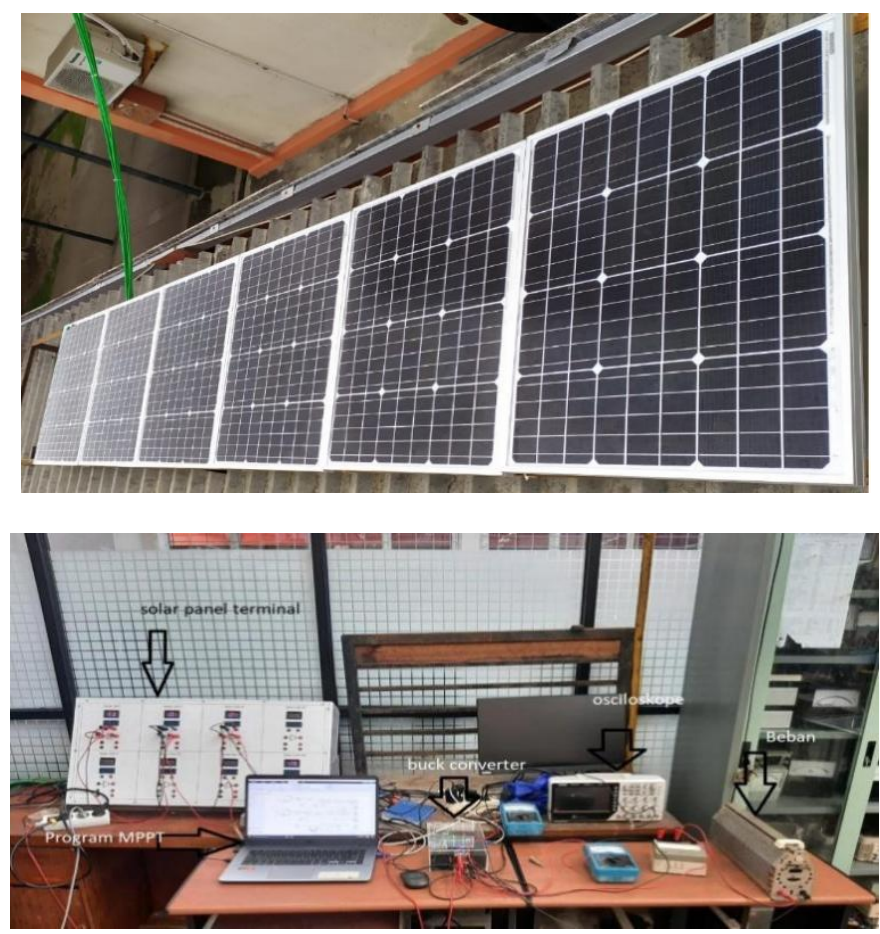

Gambar 6. Instalasi Panel Surya dan alat MPPT

Pengujian dilakukan untuk melihat daya, tegangan dan arus panel surya. Pengujian dilakukan pada jam 11.00 WIB pagi hari. Gambar 7 menunjukan grafik tegangan panel surya yang menjadi input konverter buck yang diplot dengan menggunakan osiloskop. Gambar 7 menunjukan bahwa tegangan panel surya sebelum dipasang MPPT sekitar 19 Volt.

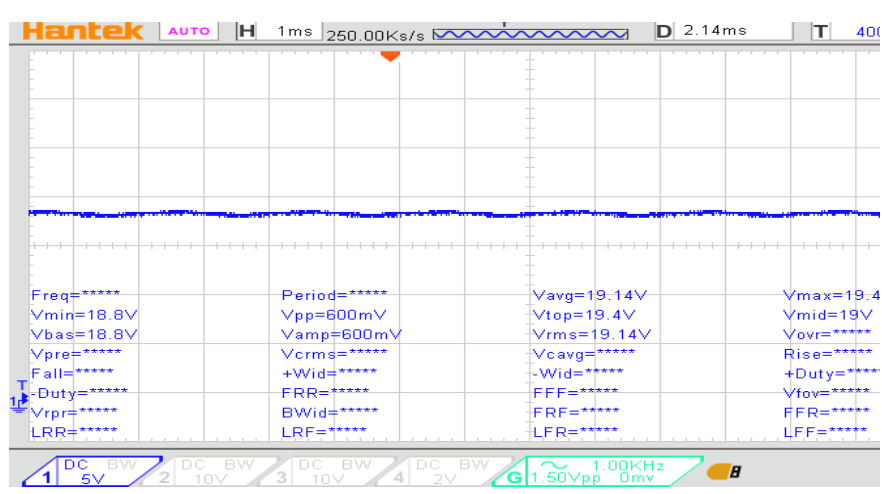

Gambar 7. Tegangan panel surya sebelum MPPT
Selanjutkan program MPPT dijalankan di Simulink Matlab. Gambar 8 menunjukan grafik tegangan dan arus panel surya setelah dipasang MPPT yang diplot dalam Simulink Matlab. Grafik tegangan pada Gambar 8(a) menunjukan bahwa tegangan keluaran panel surya Ketika dipasangi MPPT sekitar 15 Volt, sedangkan tegangan keluaran konverter buck rata-rata pada kondisi ini sekitar 9 Volt.

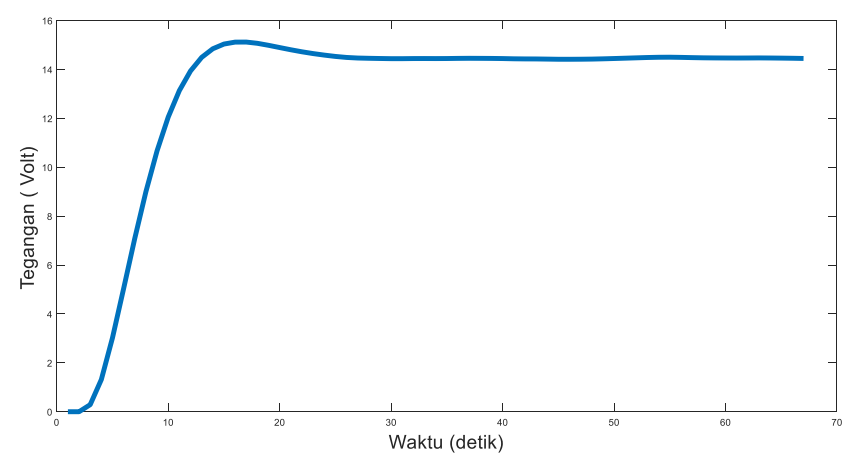

(a)

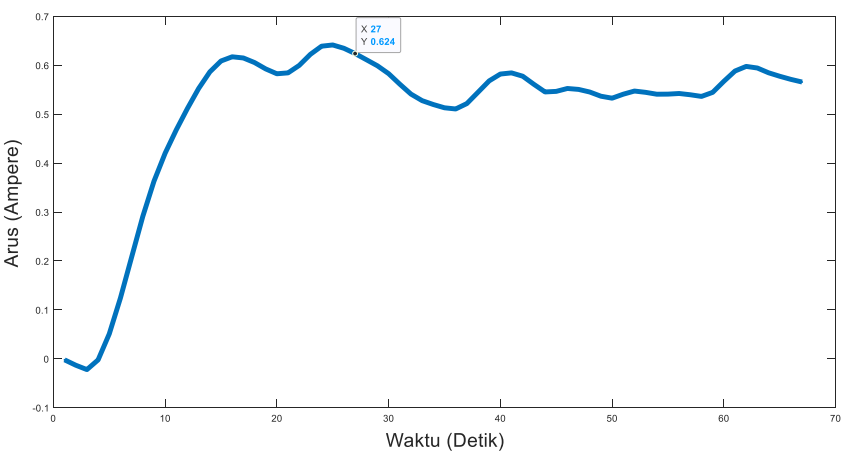

(b)

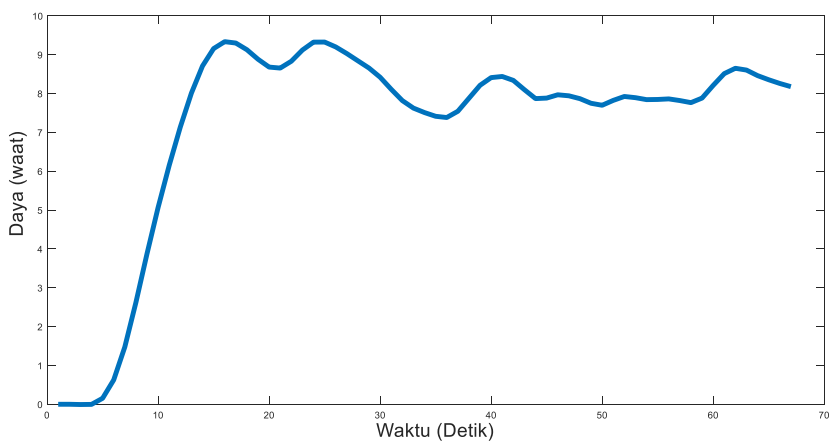

(c)

Gambar 8.(a) Tegangan panel surya setelah MPPT (b) arus panel surya setelah MPPT (c) daya panel surya setelah MPPT 
Gambar 8(c) menunjukan bahwa pada kondisi awal grafik daya bergerak dari bawah mencapai titik maksimum. Selanjutnya terjadi perubahan nilai daya yang mungkin disebabkan oleh perubahan radiasi dan temperatur pada panel surya. Hal ini menunjukan bahwa algoritma MPPT bekerja mencari titik maksimum daya panel surya dengan cara mengatur tegangan keluaran panel surya melalui konverter daya. Kinerja sistem MPPT yang baik ini tidak terlepas dari validitas algoritma PO mencari nilai duty cycle tegangan panel surya pada titik daya maksimum yang dibuat dalam Simulink Matlab dan kinerja konverter buck dalam mengendalikan tegangan panel surya. Gambar 9 menunjukan grafik tegangan keluaran konverter buck dan pulsa modulasi PWM yang dihasilkan Arduino untuk gate driver konverter buck yang diplot dengan menggunakan osiloskop.

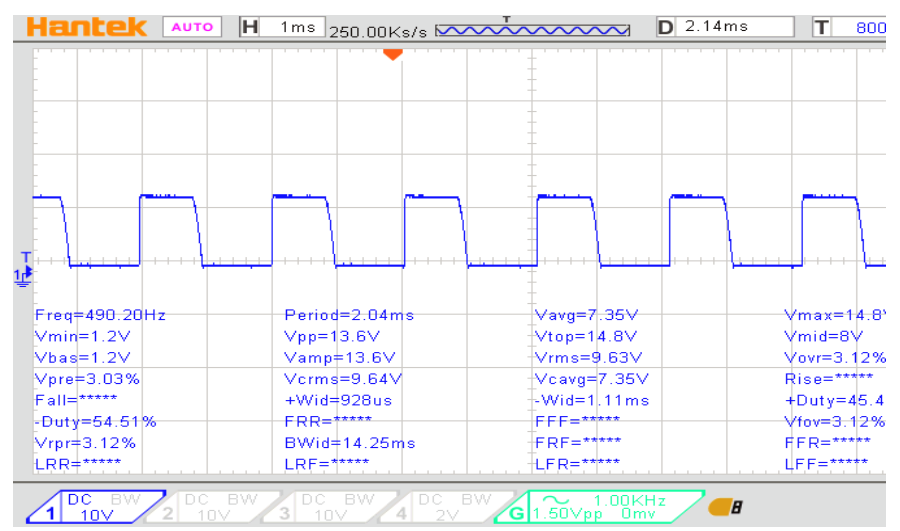

(a)

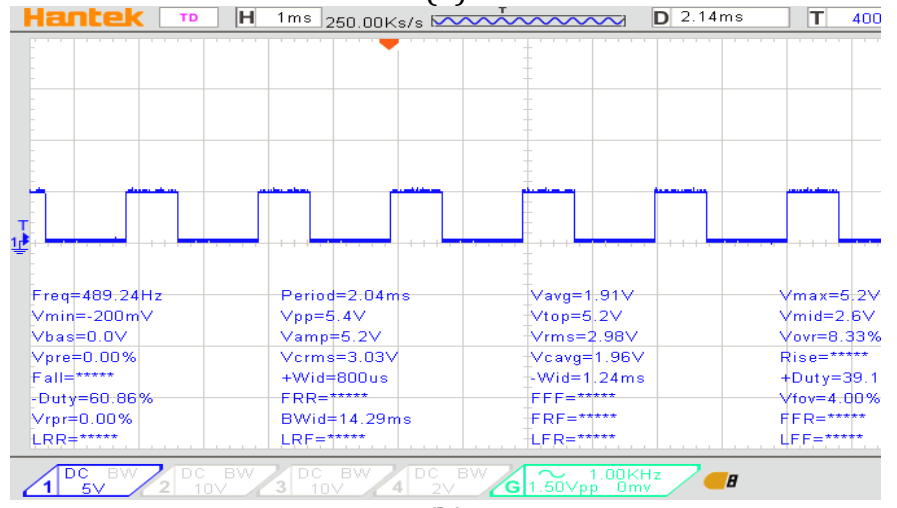

(b)

\section{Gambar 9. Performansi konverter buck, (a) tegangan keluaran dan (b) Pulsa PWM.}

Gambar 9 menunjukan bahwa konverter buck yang dibuat untuk sistem kendali MPPT telah bekerja sesuai dengan fungsinya. Gambar 9(a) menunjukan bahwa pada saat algoritma MPPT bekerja, tegangan keluaran rata-rata konverter buck sekitar 9 Volt ketika tegangan inputnya sekitar 15 Volt. Hal ini menunjukan bahwa konverter buck telah bekerja dengan baik, dimana tegangan keluarannya lebih rendah dari tegangan inputnya. Hasil ini diperoleh berdasarkan pulsa PWM yang dihasilkan arduino dari algoritma MPPT berbasis PO dalam simulink matlab, seperti yang ditunjukan oleh Gambar 9(b).

Semua hasil ini menunjukan bahwa sistem kendali MPPT yang dirancang menggunakan konverter buck berbasis algoritma PO yang diimplementasikan dengan arduino telah bekerja dengan baik dalam mengendalikan daya output panel surya pada titik maksimum.

\section{PENUTUP}

Sistem kendali MPPT untuk panel surya dirancang untuk mendapatkan daya maksimum pada setiap saat. Penelitian ini mengusulkan sistem kendali MPPT berbasis algoritma PO dengan menggunakan converter buck yang diimpelementasikan dengan Arduino Mega 2560 sebagai pusat kontrolnya. Sistem kendali MPPT dirancang untuk empat buah panel surya 50 WP yang dipasang secara parallel. Hasil pengujian yang dilakukan menunjukan system kendali MPPT yang diusulkan telah bekerja dengan baik, dimana daya output panel surya telah dapat dikendalikan di sekitar titik daya maksimum setiap saatnya.

\section{REFERENSI}

[1] A. Faizal and B. Setyaji, "Desain Maximum Power Point Tracking (MPPT) pada Panel Surya Menggunakan Metode Sliding Mode Control," J. Sains, Teknol. dan Ind, vol. 14, pp. 22-31, 2016.

[2] R. Fernandes dan M. Yuhendri, "Implementasi Solar Tracker Tanpa Sensor pada Panel Surya," JTEV, vol. 6, pp. 337-343, 2020.

[3] J. A. Hamonangan, "Review perbandingan teknik Maximum Power Point Tracker (MPPT) untuk sistem pengisian daya menggunakan sel surya," J. Teknologi Dirgantara, vol. 16, pp. 111, 2019.

[4] G. Dileep and S. N. Singh, "Selection of non-isolated DC-DC converters for solar photovoltaic system," Renewable and Sustainable Energy Reviews," vol. 76, pp. 1230-1247, 2017.

[5] A. Dehghanzadeh., G. Farahani., H. Vahedi and K. AlHaddad, "Model predictive control design for DC-DC converters applied to a photovoltaic system," Int. Journal of Electrical Power \& Energy Systems, vol. 103, pp. 537-544, 2018.

[6] A. Anggawan and M. Yuhendri, "Implementasi kendali tegangan output buck converter berbasis Simulink Matlab, Jurnal Teknik Elektro Indonesia, vol. 2, pp. 3439, 2020.

[7] B. Bendib, H. Belmili, and F. Krim, "A survey of the most used MPPT methods: conventional and advanced algorithms applied for photovoltaic systems," Renewable and Sustainable Energy Review, vol. 45, pp. 637-648, 2015. 
[8] I. Winarno and L. Natasari, "Maximum Power Point Tracker (MPPT) berdasarkan metode perturb and observe dengan sistem tracking panel surya single axis," in Proc. Semnastek, 2017, P. 1.

[9] S. Utami, "Implementasi algoritma perturb and observe untuk mengoptimasi daya keluaran solar cell menggunakan MPPT di Laboratorium Energi Baru Terbarukan," Jurnal Infotel, vol. 9, pp. 92-97, 2017.

[10] W. B. Pramono, D. A. R. Wati, and M. V. T. Yadaka, "Simulasi Maximum Power Point Tracking pada Panel Surya Menggunakan Simulink MATLAB," in Proc. Semnas IX ReTII, 2014. p. 176.

[11] P. Kofinas, S. Doltsinis, A.I Dounis dan G.A Vouros, “ A reinforcement learning approach for MPPT control method of photovoltaic sources," Renewable Energy, vol. 108. Pp. 461-473, 2017

[12] G. S. Putra and M. Yuhendri, "Implementasi system kendali MPPT panel surya berbasis algoritma incremental conductance, Jurnal Teknik Elektro Indonesia, vol. 1, pp. 218-223, 2020.

[13] S.Saravanan and R. Babu N. 2016, "Maximum power point tracking algorithms for photovoltaic system - A review," Renewable and Sustainable Energy Reviews, vol. 57, pp. 192-204, 2016
[14] G. Wibisono, S. H. Pramono, and M. A. Muslim, "MPPT menggunakan metode hibrid JST dan algoritma genetika untuk sistem photovoltaic," J. EECCIS, vol. 8, pp. 181-186, 2014.

[15] Aswardi, M. Yuhendri dan D. T. Yanto, Teknik Elektronika Daya, Indonesia : IRDH Book Publisher, 2020.

\section{Biodata Penulis}

Haris masrepol, dilahirkan di Payakumbuh, 17 Oktober 1997, menyelesaikan Program Study DIV Teknik Elektro Industri pada jurusan Teknik Elektro Fakultas Teknik Universitas Negeri Padang.

Dr. Muldi Yuhendri, S.Pd, MT, lahir di Kampung Aur, 13 Desember 1981. Sarjana Pendidikan Teknik Elektro, Universitas Negeri Padang tahun 2005, S2 Teknik Elektro Sistem Tenaga, ITS tahun 2009, S3 Ilmu Teknik Elektro, ITS tahun 2017. Staf pengajar pada jurusan teknik elektro FT UNP sejak tahun 2006 sampai sekarang 